\title{
TRANSPORT POWER PLANTS WITH ROTARY PISTON AIR ENGINES
}

\author{
Mytrofanov O. S., Proskurin A. Yu.
}

\section{INTRODUCTION}

Today, road transport with internal combustion engines is one of the most popular ways to move. However, despite a number of significant advantages, this type of transport has its own disadvantages. The main ones are significant environmental pollution and the unstable cost of petroleum products.

An alternative to traditional transport plants nowadays is plants with environmentally friendly types of energy - electric ${ }^{1,2,3}$ and hybrid vehicles $^{4,5,6}$. But they are not perfect either. Along with significant advantages, there are also problems associated with their high cost, long charging time, underdeveloped infrastructure and low autonomy.

Compressed air vehicles ${ }^{7,8}$, or hybrid vehicles using an air engine can become a competitor to electric and hybrid transport. Air engines, just like

1 Electric surge; Carmakers' car plans across Europe 2019-2025. Transport \& Environment. European Federation for Transport and Environment AISBL, 2019. 39 p.

2 Hooftman N., Oliveira L., Messagie M., Coosemans T., Mierlo J.V. Environmental Analysis of Petrol, Diesel and Electric Passenger Cars in a Belgian Urban Setting. Energies. 2016. Vol. (84). Pp. 1-24.

${ }^{3}$ Crisostomi E., Shorten R., Stüdli S., Wirth F. Electrical and Plug-in Hybrid Vehicle Networls: Optimization and Control. Taylor \& Francis Group, 2018. 261 p.

${ }^{4}$ Капустин А.А., Раков В.А. Гибридные автомобили : учебное пособие. М-во образования и науки Рос. Федерации, Вологод. гос. ун-т. Вологда : ВолГУ, 2016. 95 с.

${ }^{5}$ Петров Р.Л. На сколько реальны заявленные показатели расхода топлива и эмиссии $\mathrm{CO}_{2}$ для гибридных автомобилей. Журнал автомобильных инженеров. 2015. № 2 (31). С. 45-50.

${ }^{6}$ Бажинов О.В., Смирнов О.П., Сєріков С.А. Гібридні автомобілі. Харків : Крок, 2008. 327 с.

${ }^{7}$ Wasbari F., Bakar R.A., Gan L.M., Tahir M.M., Yusof A.A. A review of compressed-air hybrid technology in vehicle system. Renew Sustain Energy Rev. 2017. No. 67. Pp. 935-953.

${ }^{8}$ Radhika S., Swapna D., Manikanta P., Sunain S.K. Design of a compressed air vehicle. Journal of Refrigeration, Air Conditioning, Heating and Ventilation. 2016. No. 1 (3). Pp. 1-6. 
electric engines, are environmentally friendly, in addition, there is the possibility of refueling at home, they have low cost due to the simplicity of their design, it is possible to use an energy recuperator (for example, compression and accumulation of additional air by car deceleration).

The main element of such a transport power plant is the air engine, the technical perfection of which directly determines the effective and operational indicators of the entire plant.

A significant number of researchers went by converting a conventional four-stroke engine into a two-stroke air engine $e^{9,10,11,12,13}$. This way has several disadvantages, primarily due to the fact that the design of the internal combustion engine provides for the combustion process, and not just the expansion process, as in an air engine.

The most expedient is the development and creation of a new reliable and efficient air engine that meets the specifics and satisfies all the vehicle operating conditions.

\section{Design features and operating principle of rotary piston air engines}

The machine-manufacturing enterprise Motor-Plus LLC has scientific and technical base, many years of experience in the design and creation of new models of engines and various equipment and originates from the Ukrainian Scientific Research Institute of Shipbuilding Technology (a division of which it was). This enterprise has designed a rotary piston air engine of a new design, which combines the advantages of piston and rotary air engines ${ }^{14}$. In addition, several samples of such air engines were manufactured and tested.

9 Pramod K.J. Air powered engine. International Journal of Mechanical Engineering and Technology (IJMET). March-April 2016. No. 7 (2). Pp. 66-72.

${ }^{10}$ Allam S., Zakaria M. Experimental Investigation of Compressed Air engine Performance. International Journal of Engineering Inventions. February 2018. No. 7 (1). Pp. 13-20.

${ }^{11}$ Vishwajeet S. Compressed Air Engine. International Journal of Scientific and Research Publications. 2017. No. 7 (7). Pp. 403-412.

12 Kumar N.P., Shankar N.V.S., Prasad Reddy V.S.S.N. Performance of a compressed air engine. Int J Res Appl Sci Eng Technol. 2018. No. 6. Pp. 2456-2466.

13 Radhakrishna L., Gopikrishna N. Prefabricating and testing of air driven engine. Int J Mech Eng Technol. 2017. No. 8(11). Pp. 238-251.

14 Митрофанов О.С., Шабалін Ю.В., Бірюк Т.Ф., Сфеніна Л.О. Пат. на винахід України № 120489. Поршнева машина. 2019. Заявл. № а201902189, бюл. № 23. 
The developed rotary piston air engine of a fundamentally new design meets all the specified requirements and can be used as part of a transport power plant as an auxiliary or main engine, and the study of its characteristics and operating modes as part of a power plant is a very important and crucial task.

Fig. 1 shows the general design of rotary piston engines. The rotary piston air engine contains housing 1 , which houses rotor 2 with 12 radially opposed cylinders 3 and 12 pistons 4 located in them. The pistons are interconnected by means of pins 5 and movable links 6 and thus form a four-bar linkage, in the middle of which cam 7 is arranged coaxially with rotor 2. Cam 7 has two diametrically opposite vertices and contacts links 6 , which form the lateral sides of the four-bar linkage. In this case, cam 7 is made in the form of a rod with a crosssection in the form of a curved rhombus with rounded tops and has the ability to rotate around its own axis.

The lateral surface of each of links 6 is made with a radius of $R$ and has grooves 8 , which are bounded by an arc of a circle with a radius equal to the radius of curvature of top of cam 7. Moreover, the curves limiting the cross section of the rod and lying on both sides of the small diagonal of the rhombus are made in the form of circular arcs. The center of one circle with radius $r$ lies on the smaller diagonal of the rhombus, and the center of another circle with radius $R$ lies on the link radius center line.

The distance between the tops of cam 7 is equal to the difference between the lengths of the larger and smaller diagonals of the rhombus formed by the axes of links 6 when pistons 4 are in the dead center of the figure.

The rotary piston air engine works as follows. Compressed air is supplied through oppositely located inlet receivers into the working cylinders, where it acts on the pistons of the four-bar linkage, as a result of which they begin to move to the center of the rotor axis, that is, to the bottom dead center.

In this case, the second pair of pistons moves from the center to the top dead center. Resting with rounded grooves on the rounded tops of the stationary cam, the movable links rotate, as a result of which a rotational movement is given to the rotor. Pistons that move from the center of the axle to the top dead center push the remnants of the exhausted working fluid into the outlet receiver. 


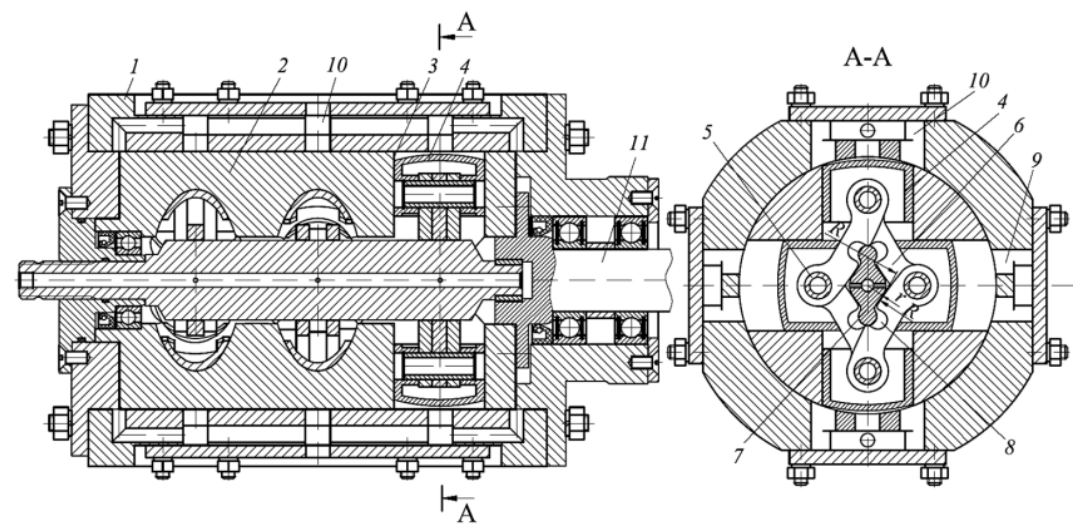

Fig. 1. General design of a rotary piston air engine:

1 - air engine housing; 2 -rotor; 3 -working cylinder; 4 -piston;

5 - piston pin; 6 - movable link; 7 - regulating cam; 8 - groove;

9 - inlet receiver; 10 - outlet receiver; 11 - power take-off shaft

The rotary piston air engine has uniformly spaced cylinders, which ensures the balance of the engine and the ability to start at any position of the rotor.

The ratio of the piston stroke $S$ to the cylinder diameter $D$ is less than one $(S / D<1)$, that is, the rotary piston air engine is short-stroke one. This reduces the pressure loss of the compressed air at the inlet and reduces the back pressure of the exhaust air at the outlet.

In the developed design of the rotary piston air engine, inlet and outlet openings are used for air distribution, the overlap of which is carried out by a central rotor. Thus, the central rotor acts as a spool and housing in which the pistons move. The use of spool air distribution provides a fairly simple and compact design. At the same time, due to the proposed design of the movement mechanism, the value of the relative dead volume is insignificant and is due only to the technological clearances.

The design of the air engine provides for the possibility of regulating the operating modes by changing the degree of filling of the working cylinder. This is done by rotating the control cam around its axis. Also, by turning the control cam at a certain angle, the air engine is reversible. At the same time, due to the symmetry of the structure, the reversal of the air engine does not affect its efficiency. 


\section{Transport power plant with rotary piston air engine}

The simplest and most compact scheme of a power transport plant can be a scheme in which the change in the torque on the driving wheels is carried out by changing the torque of the air engine (Fig. 2). The torque from rotary piston air engine $l$ is transmitted through viscous clutch 2 and reducer 3 to the rear drive wheels. The air engine is powered from supply cylinders 8 . The torque of the air engine is changed by increasing or decreasing the operating pressure in the inlet receiver of the air engine using electronically controlled air reducer 9 .

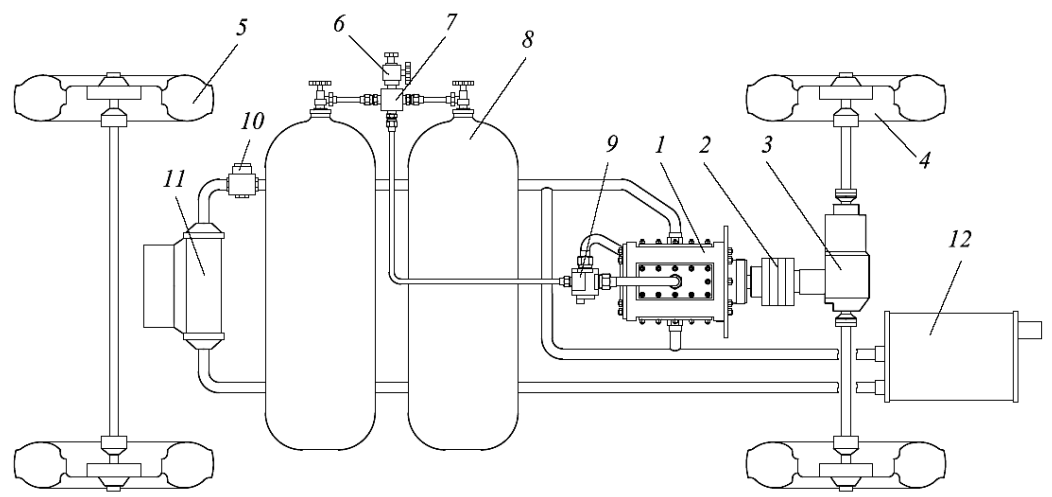

Fig. 2. Layout scheme of a transport power plant with variable working pressure of the air engine:

1 - rotary piston air engine; 2 - viscous clutch; 3 - rear wheel reducer; 4 -wheels of the rear driving axle; 5 - wheels of the front non-driving axle;

6 - valve for filling supply cylinders from an external source;

7 - compressed air distributor; 8 - compressed air storage cylinders; 9 - electronically controlled air reducer; 10 - exhaust air bypass valve;

11 - heat exchanger of the vehicle air conditioning system; 12 - exhaust air muffler

The cylinders are filled with compressed air through filling valve 6 . Two to four cylinders with a volume of $0.1 \mathrm{~m}^{3}$ each with an air storage pressure of up to $35 \mathrm{MPa}$ can be installed on vehicle board. To reduce the weight of the power plant, the cylinders can be made of carbon fiber reinforced plastic with Kevlar shell. Such a scheme allows to provide structural simplicity, minimum weight, and ease of control of the power 
plant. At the same time, the main disadvantage of such scheme is a significant decrease in the drive range.

A decrease in drive range is associated with the need to limit the discharge of the supply cylinders to the maximum required working pressure, which ensures the start of the vehicle movement. That is, there is an actual decrease in the air actually used in the system. The main parameters of the transport power plant with variable operating pressure of the air engine are given in Table 1.

Table 1

Main characteristics of the transport power plant with variable working pressure of the air engine

\begin{tabular}{|c|c|c|c|}
\hline No. & Parameter & Designation/dimension & Value \\
\hline 1 & Gross vehicle weight & $m, \mathrm{~kg}$ & 680 \\
\hline 2 & Vehicle wheel static radius & $R, \mathrm{~m}$ & 0.289 \\
\hline 3 & $\begin{array}{c}\text { Vehicle dimensions: } \\
\text { - length } \\
\text { - width } \\
\text { - height }\end{array}$ & $\begin{array}{l}L, \mathrm{~m} \\
B, \mathrm{~m} \\
H, \mathrm{~m}\end{array}$ & $\begin{array}{l}3.40 \\
1.62 \\
1.40\end{array}$ \\
\hline 4 & Number of passengers & - & 4 \\
\hline 5 & Final drive gear ratio & $u_{k 0}$ & 5,4 \\
\hline 6 & $\begin{array}{c}\text { Compressed air storage } \\
\text { cylinder volume }\end{array}$ & $V, \mathrm{~m}^{3}$ & 0,1 \\
\hline 7 & Number of cylinders & $i_{c}$ & $2 \ldots 4$ \\
\hline 8 & Weight of cylinders & $M_{c}, \mathrm{~kg}$ & 35 \\
\hline 9 & $\begin{array}{l}\text { Maximum air pressure } \\
\text { in cylinders }\end{array}$ & $p_{c}, \mathrm{MPa}$ & 35 \\
\hline 10 & Maximum travel speed & $V_{\text {p.max }}, \mathrm{km} / \mathrm{h}$ & 40 \\
\hline 11 & Working pressure range & $P_{s}, \mathrm{Mpa}$ & $1.2 \ldots 6.5$ \\
\hline 12 & $\begin{array}{l}\text { Effective power } \\
\text { (at } P_{s}=6.5 \mathrm{MPa} \text { ) }\end{array}$ & $N_{e}, \mathrm{~kW}$ & 17 \\
\hline 13 & $\begin{array}{l}\text { Maximum torque } \\
\text { (at } P_{s}=6.5 \mathrm{MPa} \text { ) }\end{array}$ & $M_{t}, \mathrm{~N} \cdot \mathrm{m}$ & 131 \\
\hline 14 & $\begin{array}{c}\text { Maximum rpm } \\
\text { of the central rotor }\end{array}$ & $n, \mathrm{rpm}$ & 2000 \\
\hline
\end{tabular}

According to the data presented in Table 1, the minimum discharge pressure of the supply cylinders cannot decrease below $6.5 \mathrm{MPa}$ in terms of ensuring the required torque on the vehicle wheels at the moment of acceleration. More promising is the use of a gearbox to ensure a change in torque during acceleration of a vehicle, while the operating pressure in the air engine remains constant. 
Fig. 3 shows a layout diagram of a transport power plant with a constant working pressure of the air engine. Unlike the first scheme, the torque from rotary piston air engine 1 is transmitted through the transmission of front drive axle 2 to wheels 3 . Compressed air from supply cylinders 7 through compressed air distributor 6 enters electronically controlled air reducer 8 , from where, under the required constant working pressure enters the inlet receiver of the rotary piston air engine.

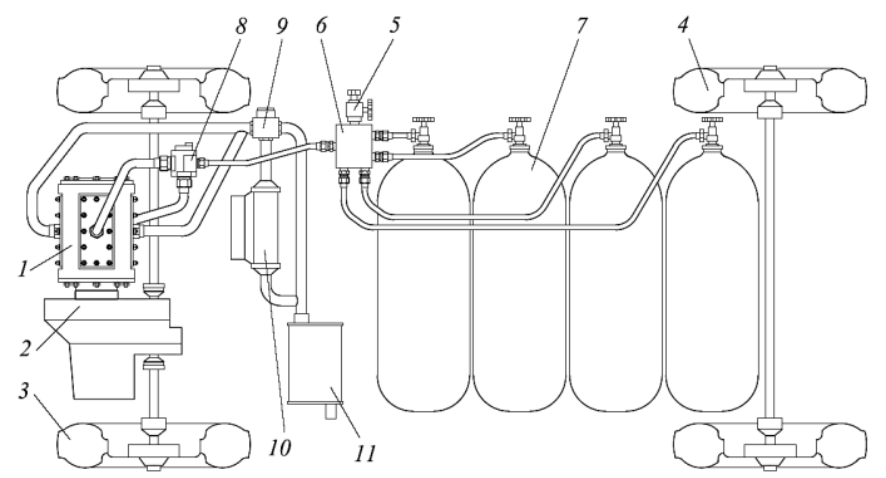

Fig. 3. Layout scheme of the transport power plant with constant working pressure of the air engine:

1 - rotary piston air engine; 2 - transmission of the front driving axle; 3 - wheels of the front driving axle; 4 -wheels of the rear non-driving axle;

5 - valve for filling supply cylinders from an external source;

6 - compressed air distributor; 7 - compressed air storage cylinders;

8 - electronically controlled air reducer; 9 - exhaust air bypass valve;

10 - heat exchanger of the vehicle air conditioning system;

$$
11 \text { - exhaust air muffler }
$$

At the outlet of the rotary piston air engine, the exhaust air has low temperatures and, accordingly, can be used in heat exchanger 10 (in the first scheme, Fig. $2-11$ ) of the vehicle air conditioning system. The exhaust air flow between the heat exchanger and the exhaust muffler is carried out by a bypass valve.

The main parameters of the transport power plant with constant operating pressure of the air engine are given in Table 2. Thus, according to the data presented in Table 2, the minimum discharge pressure of the supply cylinders is $2 \mathrm{MPa}$, which is 3.25 times less than the previous scheme. 
Main characteristics of a transport power plant with a constant working pressure of the air engine

\begin{tabular}{|c|c|c|c|}
\hline No. & Parameter & Designation/dimension & Value \\
\hline 1 & Gross vehicle weight & $m, \mathrm{~kg}$ & 720 \\
\hline 2 & Car wheel static radius & $R, \mathrm{~m}$ & 0.289 \\
\hline 3 & $\begin{array}{c}\text { Vehicle dimensions: } \\
\text { - length } \\
\text { - width } \\
\text { - height }\end{array}$ & $\begin{array}{l}L, \mathrm{~m} \\
B, \mathrm{~m} \\
H, \mathrm{~m}\end{array}$ & $\begin{array}{l}3.40 \\
1.62 \\
1.40\end{array}$ \\
\hline 4 & Number of passengers & - & 4 \\
\hline 5 & Final drive ratio & $u_{k 0}$ & 5.125 \\
\hline & $\begin{array}{c}\text { Gear ratio: } \\
\text { - first } \\
\text { - second } \\
\text { - third } \\
\text { - fourth } \\
\text { - fifth }\end{array}$ & $\begin{array}{l}u_{k 1} \\
u_{k 2} \\
u_{k 3} \\
u_{k 4} \\
u_{k 5}\end{array}$ & $\begin{array}{l}4.05 \\
2.34 \\
1.40 \\
1.00 \\
0.85 \\
\end{array}$ \\
\hline 6 & $\begin{array}{c}\text { Compressed air storage } \\
\text { cylinder volume }\end{array}$ & $V, \mathrm{~m}^{3}$ & 0.1 \\
\hline 7 & Number of cylinders & $\overline{i_{c}}$ & $2 \ldots 4$ \\
\hline 8 & Weight of cylinders & $M_{c}, \mathrm{~kg}$ & 35 \\
\hline 9 & $\begin{array}{l}\text { Maximum air pressure } \\
\text { in cylinders }\end{array}$ & $p_{c}, \mathrm{MPa}$ & 35 \\
\hline 10 & Maximum travel speed & $V_{\text {p.max }}, \mathrm{km} / \mathrm{h}$ & 50 \\
\hline 11 & Working pressure range & $P_{s}, \mathrm{Mpa}$ & 2 \\
\hline 12 & $\begin{array}{l}\text { Effective power } \\
\text { (at } P_{s}=6.5 \mathrm{MPa} \text { ) }\end{array}$ & $N_{e}, \mathrm{~kW}$ & 6 \\
\hline 13 & $\begin{array}{l}\text { Maximum torque } \\
\text { (at } P_{s}=6.5 \mathrm{MPa} \text { ) }\end{array}$ & $M_{t}, \mathrm{~N} \cdot \mathrm{m}$ & 44 \\
\hline 14 & $\begin{array}{l}\text { Maximum rpm } \\
\text { of the central rotor }\end{array}$ & $n, \mathrm{rpm}$ & 2000 \\
\hline
\end{tabular}

The use of gearbox slightly complicates and increases the mass of the power plant, however, it allows discharging the supply cylinders by $94.3 \%$ and increasing the vehicle speed up to $50 \mathrm{~km} / \mathrm{h}$. Based on this, this scheme is more promising and, accordingly, requires additional analysis.

To calculate the dynamic characteristics and assess the acceleration indicators of the vehicle, it is necessary to have the speed characteristics of the air engine (i.e., the dependence of the change in torque and effective power on rpm). As a power unit in the presented schemes, it is proposed to take one of the prototypes - the 12RPD-4.4/1.75 rotary piston air engine. It is a 12-cylinder air engine with a $44 \mathrm{~mm}$ bore and $17.5 \mathrm{~mm}$ stroke. The 
nature of the change in the speed characteristics of the 12RPD-4.4/1.75 rotary piston air engine was obtained experimentally for various values of the compressed air pressure in the inlet receiver. Fig. 4 shows the external speed characteristic of the 12RPD-4.4/1.75 rotary piston air engine for various values of the working pressure $P_{s}$ in the inlet receiver.
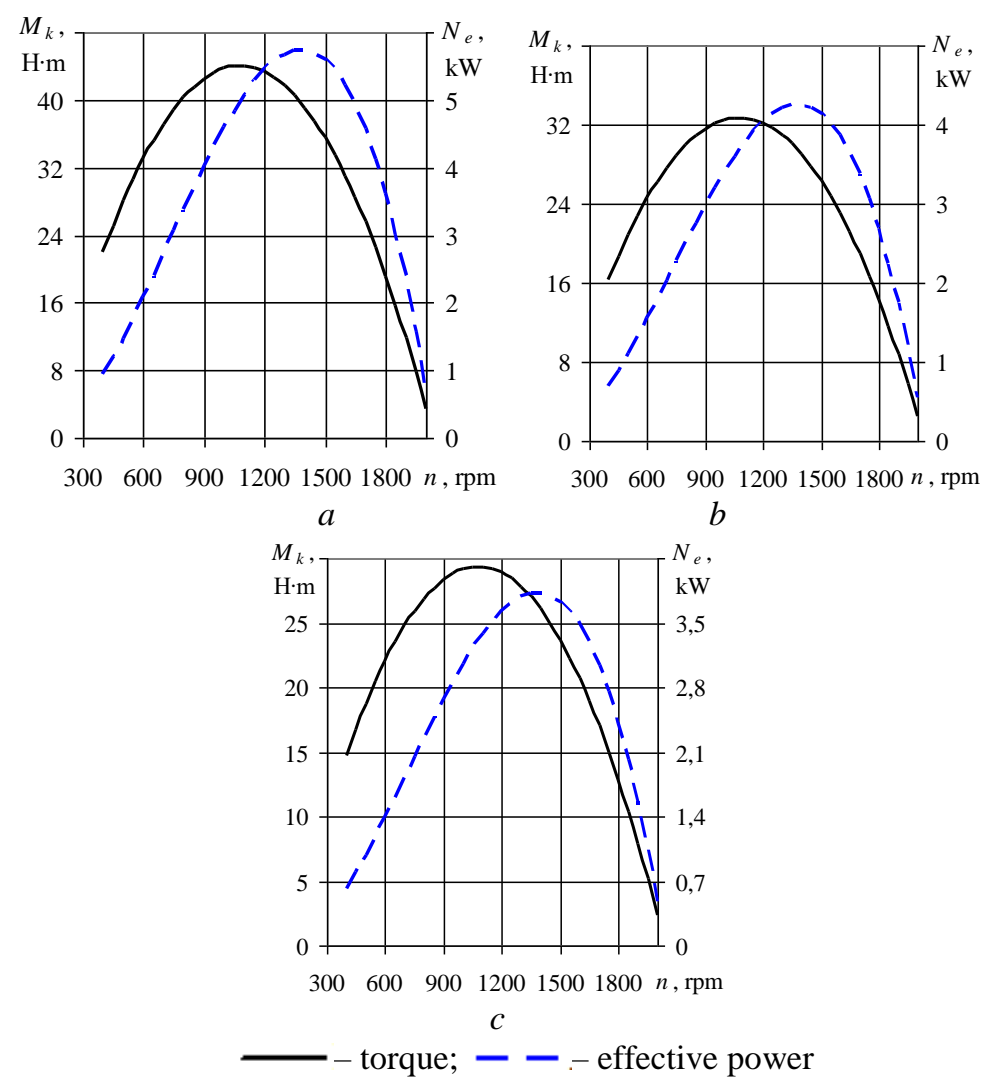

Fig. 4. External speed characteristic of the 12RPD-4.4/1.75 rotary piston air engine depending on the working pressure of compressed air in the inlet receiver: $a-P_{s}=2.0 \mathrm{MPa} ; b-P_{s}=1.4 \mathrm{MPa} ; c-P_{s}=1.2 \mathrm{MPa}$

So, depending on $P_{s}$, the maximum torque of the air engine is in range $M_{t}=29 \ldots 44 \mathrm{~N} \cdot \mathrm{m}$, and the effective power $N_{e}=4 \ldots 6 \mathrm{~kW}$. 
The power balance and dynamic characteristics of a vehicle are usually built on the vehicle speed, and not on the air engine speed ${ }^{15,16}$.

First of all, the vehicle speed depends on the change in the air engine speed, as well as on constant components, such as the static radius of the wheel $R$, the gear ratio of the gearbox $u_{k i}$ and the final drive ratio $u_{k 0}$. Fig. 5 shows the graphs of the power balance and the dynamic characteristics of a vehicle with a rotary piston air engine for various values of $P_{s}$.

So, according to the obtained dependencies, the 12RPD-4.4/1.75 rotary piston air engine in combination with transmission in the range of $P_{s}=1.2 \ldots 2.0 \mathrm{MPa}$ provides the maximum tractive effort of $2.1 \ldots 3.2 \mathrm{kN}$ in the first gear.

The dynamics of vehicle acceleration is characterized by acceleration, as well as time and distance of acceleration to the required speed. Fig. 6 shows the dependences of the change in acceleration and reverse acceleration at various values of pressure $P_{s}$. Acceleration values for all gears and speeds were obtained using dynamic characteristics (see Fig. 5) and known dependencies.

The graphs of the time and path of acceleration of a vehicle with a rotary piston air engine to maximum speed are shown in Fig. 7. In accordance with the obtained dependencies, the air engine at $P_{s}=2.0$ $\mathrm{MPa}$ provides vehicle acceleration to the maximum speed in $20.1 \mathrm{~s}$, while the acceleration path will be $200.2 \mathrm{~m}$. When the air pressure in the inlet receiver decreases to $P_{s}=1,2 \mathrm{MPa}$, the acceleration time will be $30.5 \mathrm{~s}$, and the path will be $309.3 \mathrm{~m}$. Therefore, a $40 \%$ decrease in air pressure increases the vehicle acceleration time by almost $52 \%$. However, a decrease in the operating pressure in the inlet receiver provides a decrease in compressed air consumption, that is, in fact, an increase in the drive range. So, according to experimental studies of the prototype of the 12RPD-4.4/1.75 rotary piston air engine, a 50\% decrease in air pressure in the inlet receiver ensures a decrease in the specific effective air consumption by $18.3 \%$. The implementation of the adjustment of the working pressure in the inlet receiver of the air engine into the scheme, shown in Fig. 3, will provide high values of the torque at the beginning of the movement of the vehicle and reduce the consumption of compressed air.

15 Филькин Н.М., Шаихов Р.Ф., Буянов И.П. Теория транспортных и транспортно-технологических машин : учебное пособие. Пермь : ФГБОУ ВО Пермская ГСХА, 2016. 230 с.

16 Тяговый расчет автомобиля: метод. указания к курсовому проектированию по дисциплине «Конструкция и потребит. свойства автомобилей». Владим. гос. ун-т им. А.Г. и Н.Г. Столетовых / сост. Р.В. Нуждин. Владимир : Изд-во ВлГУ, 2018. 36 с. 

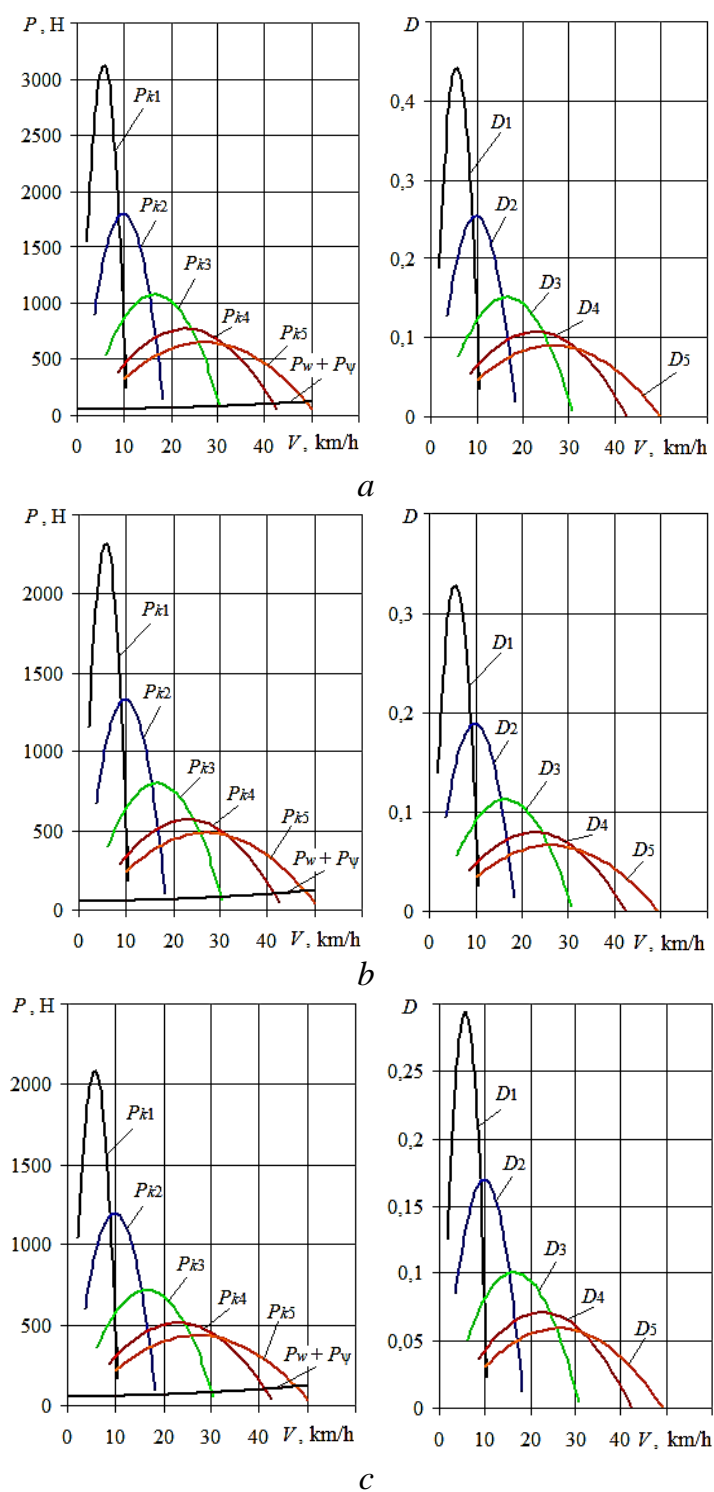

Fig. 5. Power balance and dynamic characteristics of a vehicle with the 12RPD- 4.4/1.75 rotary piston air engine: $a-P_{s}=2.0 \mathrm{MPa} ; b-P_{s}=1.4 \mathrm{MPa} ; c-P_{s}=1.2 \mathrm{MPa}$ 

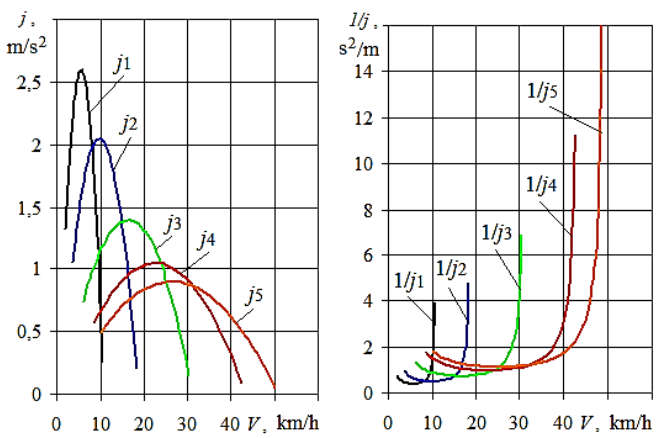

$a$
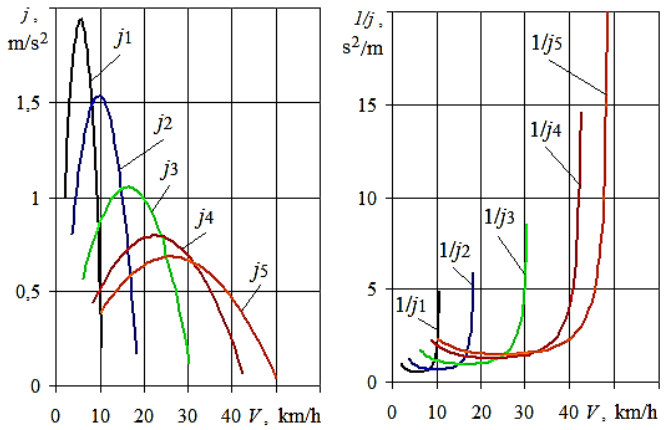

b
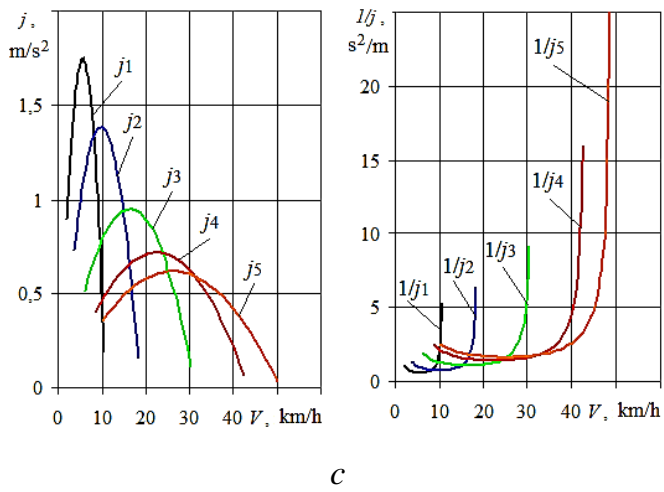

Fig. 6. Characteristics of acceleration of a vehicle with the 12RPD-4.4/1.75 rotary piston air engine: $\mathrm{a}-P_{s}=2.0 \mathrm{MPa} ; \mathrm{b}-P_{s}=1.4 \mathrm{MPa} ; \mathrm{c}-P_{s}=1.2 \mathrm{MPa}$ 


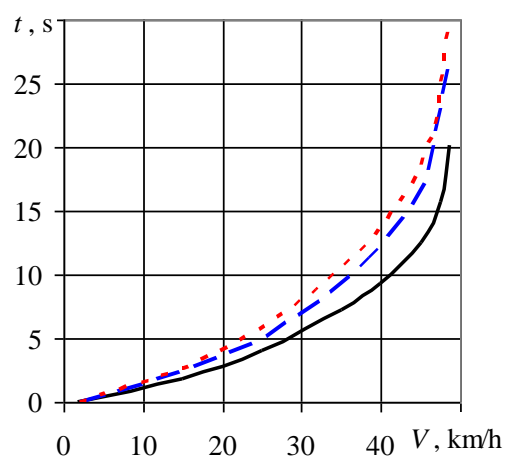

$a$

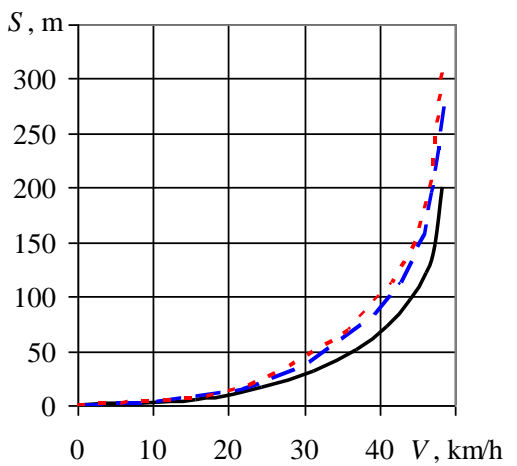

$b$

$\longrightarrow-P_{s}=2,0 \mathrm{M \Pi а}---P_{s}=1,4 \mathrm{M \Pi а;} \mathrm{-} \mathrm{-} \mathrm{-} \mathrm{-}-P_{s}=1,2 \mathrm{M \Pi а}$

Fig. 7. Dependences of the time and path of acceleration of a vehicle with the 12RPD-4.4/1.75 rotary piston air engine:

$$
\text { a-acceleration time; } b \text {-acceleration path }
$$

Thus, at the beginning of the movement, the working pressure will be 2.0 $\mathrm{MPa}$, and with a gradual increase in vehicle speed, its value will decrease to 1.2 MPa. Fig. 8 shows the range of changes in the torque and effective power of the rotary piston air engine with a variable value of the working pressure in the inlet receiver.

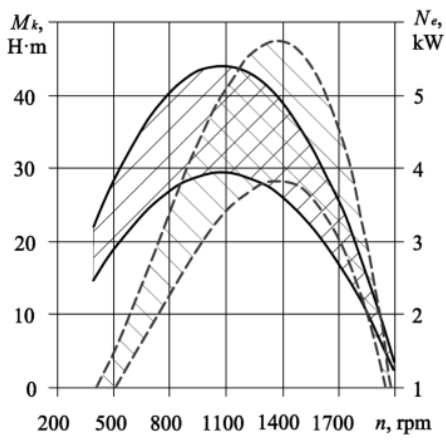

- - torque; - - - effective power

Fig. 8. Range of change of the external speed characteristic of the 12RPD-4.4/1.75 rotary piston air engine with a variable value of pressure $P_{s}$ 
Fig. 9 shows the graphs of the power balance and dynamic characteristics of a vehicle with an air engine at a variable value of pressure $P_{s}$.
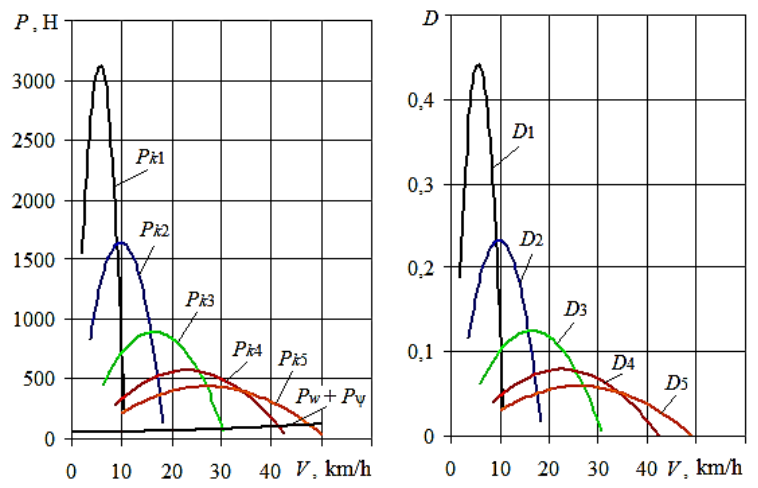

Fig. 9. Power balance and dynamic characteristics of a vehicle with the 12RPD-4.4/1.75 rotary piston air engine with a variable value of pressure $P_{s}$

Fig. 10 shows the dependences of changes in accelerations and reverse accelerations for all gears and speeds at variable values of pressure $P_{s}$.
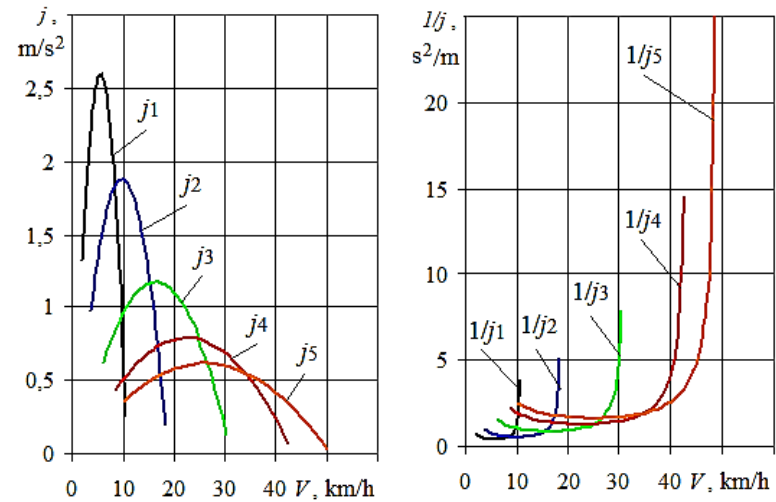

Fig. 10. Characteristics of acceleration of a vehicle with the 12RPD-4.4/1.75 rotary piston air engine with a variable value of pressure $P_{s}$ 
The graphs of the time and distance of acceleration of the vehicle to the maximum speed with a variable value of the working pressure in the inlet receiver is shown in fig. 11.

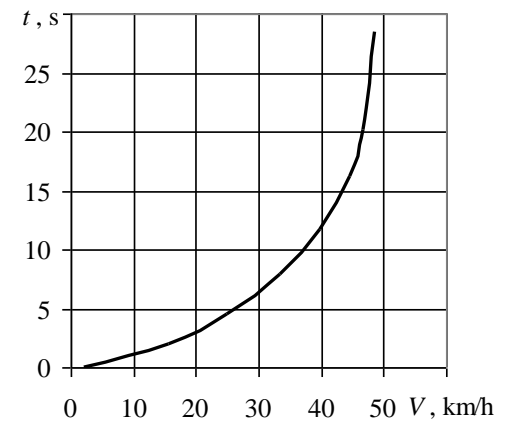

$a$

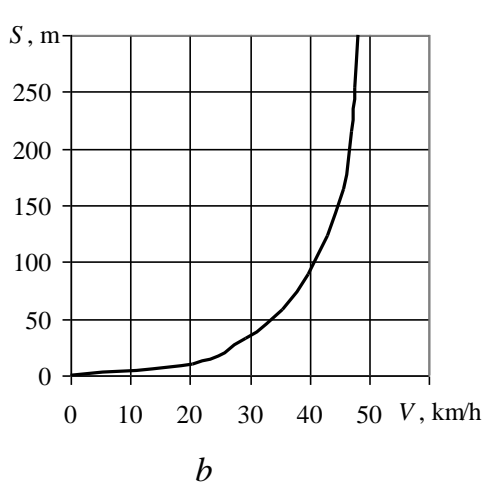

$b$

Fig. 11. Dependences of the time and path of acceleration of a vehicle with the 12RPD-4.4/1.75 rotary piston air engine with a variable value of pressure $P_{s}: a$-acceleration time; $b$-acceleration path

According to the obtained dependences, when $P_{s}$ changes in the range of 2.0..1.2 MPa, the vehicle accelerates to the maximum speed in $28 \mathrm{~s}$, while the speed of $30 \mathrm{~km} / \mathrm{h}$ is reached in $6.5 \mathrm{~s}$ (with $P_{s}=1.2 \mathrm{MPa}$, the speed of $30 \mathrm{~km} / \mathrm{h}$ is reached in $8 \mathrm{~s}$ ). Thus, the regulation of pressure $P_{s}$ at various operating modes of a rotary piston air engine is an effective method for improving the economic and operational characteristics of a transport power plant.

\section{CONCLUSIONS}

1. Layout schemes of environmentally friendly transport power plants based on the 12RPD-4.4/1.75 rotary piston air engine have been developed. The proposed air engine at an operating air pressure in the inlet receiver of 2.0 MPa provides a maximum effective power of $6 \mathrm{~kW}$ and a torque of $44 \mathrm{~N} \cdot \mathrm{m}$.

2. The external speed characteristics of the 12RPD-4.4/1.75 rotary piston air engine for the range of values of the working air pressure of 1.2...2.0 MPa in the inlet receiver were obtained. According to the data presented in this work, the air engine has a maximum torque 
$\left(M_{t}=29 \ldots 44 \mathrm{~N} \cdot \mathrm{m}\right)$ at $1100 \mathrm{rpm}$, and effective power $\left(N_{e}=4 \ldots 6 \mathrm{~kW}\right)$ at $1400 \mathrm{rpm}$.

3. The components of the power balance and the dynamic factor of the vehicle have been determined for all gears and speeds in the range of values of the working air pressure of 1.2...2.0 MPa in the inlet receiver. According to the obtained characteristics, the 12RPD-4.4/1.75 rotary piston air engine together with the transmission in the first gear provides a maximum tractive effort of $2.1 \ldots 3.2 \mathrm{kN}$.

4. Dependences of acceleration, time and path of vehicle acceleration to the maximum set speed of $50 \mathrm{~km} / \mathrm{h}$ are obtained. So, depending on the air pressure in the inlet receiver, the required acceleration time is from 20.1 to $30.5 \mathrm{~s}$, and the acceleration path is from 200.2 to $309.3 \mathrm{~m}$, which is a sufficient indicator for this type of vehicle.

5. To improve the operational and economic indicators of the transport power plant, it is rational to regulate the working air pressure in the inlet receiver of a rotary piston air engine, namely, a gradual decrease in air pressure during acceleration of the vehicle, while the percentage of discharge of supply cylinders reaches $94.3 \%$.

\section{SUMMARY}

The current state and perspective directions of development of environmentally friendly transport are analyzed. Schematic diagrams of transport power plants with the use of rotary piston air engines are proposed. The device and the principle of operation of a rotary piston air engine of a fundamentally new design are described. The external speed characteristics of the 12RPD-4.4/1.75 rotary piston air engine prototype for the range of values of 1.2..2.0 MPa of the working compressed air pressure in the inlet receiver are presented. For various gears and speeds, all components of the power balance are determined and the dynamic characteristic of the vehicle is obtained. According to the obtained results of calculating the power balance, the traction force on the driving wheels, created by the rotary piston air engine at the operating pressure of $2.0 \mathrm{MPa}$, is $3.2 \mathrm{kN}$. The indicators evaluation of vehicle acceleration when operating on an air engine is carried out, namely, the dependences of acceleration, time and acceleration path are obtained. In urban traffic, depending on the operating pressure of the air engine (1.2..2.0 MPa) the required time for car acceleration to the speed of $50 \mathrm{~km} / \mathrm{h}$ is $20.1 \ldots 30.5 \mathrm{~s}$, and the distance is $200.2 \ldots 309.3 \mathrm{~m}$. To ensure an increase in the vehicle's drive range, it is proposed to regulate the working air pressure 
in the inlet receiver of the air engine, namely, a gradual decrease in air pressure during acceleration, while the percentage of discharge of the supply cylinders is $94.3 \%$.

\section{REFERENCES}

1. Electric surge; Carmakers' car plans across Europe 2019-2025. Transport \& Environment. European Federation for Transport and Environment AISBL, 2019. 39 p.

2. Hooftman N., Oliveira L., Messagie M., Coosemans T., Mierlo J.V. Environmental Analysis of Petrol, Diesel and Electric Passenger Cars in a Belgian Urban Setting. Energies. 2016. Vol. (84). Pp. 1-24.

3. Crisostomi E., Shorten R., Stüdli S., Wirth F. Electrical and Plugin Hybrid Vehicle Networls: Optimization and Control. Taylor \& Francis Group, 2018. $261 \mathrm{p}$.

4. Капустин А.А., Раков В.А. Гибридные автомобили : учебное пособие. М-во образования и науки Рос. Федерации, Вологод. гос. ун-т. Вологда : ВолГУ, 2016. 95 с.

5. Петров Р.Л. На сколько реальны заявленные показатели расхода топлива и эмиссии $\mathrm{CO}_{2}$ для гибридных автомобилей. Журнал автомобильных инженеров. 2015. № 2 (31). С. 45-50.

6. Бажинов О.В., Смирнов О.П., Сєріков С. А. Гібридні автомобілі. Харків : Крок, 2008. 327 с.

7. Wasbari F., Bakar R.A., Gan L.M., Tahir M.M., Yusof A.A. A review of compressed-air hybrid technology in vehicle system. Renew Sustain Energy Rev. 2017. No. 67. Pp. 935-953.

8. Radhika S., Swapna D., Manikanta P., Sunain S.K. Design of a compressed air vehicle. Journal of Refrigeration, Air Conditioning, Heating and Ventilation. 2016. No. 1 (3). Pp. 1-6.

9. Pramod K.J. Air powered engine. International Journal of Mechanical Engineering and Technology (IJMET). March-April 2016. No. 7 (2). Pp. 66-72.

10. Allam S., Zakaria M. Experimental Investigation of Compressed Air engine Performance. International Journal of Engineering Inventions. February 2018. No. 7 (1). Pp. 13-20.

11. Vishwajeet S. Compressed Air Engine. International Journal of Scientific and Research Publications. 2017. No. 7 (7). Pp. 403-412. 
12. Kumar N.P., Shankar N.V.S., Prasad Reddy V.S.S.N. Performance of a compressed air engine. Int J Res Appl Sci Eng Technol. 2018. No. 6. Pp. 2456-2466.

13. Radhakrishna L., Gopikrishna N. Prefabricating and testing of air driven engine. Int J Mech Eng Technol. 2017. No. 8(11). Pp. 238-251.

14. Митрофанов О.С., Шабалін Ю.В., Бірюк Т.Ф., Сфеніна Л.О. Пат. на винахід України №120489. Поршнева машина. 2019. Заявл. № a201902189, бюл. № 23.

15. Филькин Н.М., Шаихов Р.Ф., Буянов И.П. Теория транспортных и транспортно-технологических машин : учебное пособие. Пермь : ФГБОУ ВО Пермская ГСХА, 2016. 230 с.

16. Тяговый расчет автомобиля: метод. указания к курсовому проектированию по дисциплине «Конструкция и потребит. свойства автомобилей». Владим. гос. ун-т им. А.Г. и Н.Г. Столетовых / сост. Р.В. Нуждин. Владимир : Изд-во ВлГУ, 2018. 36 с.

\section{Information about authors: Mytrofanov O. S.,}

$\mathrm{PhD}$ in Engineering Sciences, Associate Professor, Associate Professor at the Department of Internal Combustion Engines, Plants and Technical Operation Admiral Makarov National University of Shipbuilding 9, Heroiv Ukrainy avenue, Mykolaiv, 54000, Ukraine

Proskurin A. Yu.,

$\mathrm{PhD}$ in Engineering Sciences, Associate Professor, Associate Professor at the Department of Internal Combustion Engines, Plants and Technical Operation Admiral Makarov National University of Shipbuilding 9, Heroiv Ukrainy avenue, Mykolaiv, 54000, Ukraine 